\title{
Board of Directors Influence on Leverage: A Conceptual Perspective
}

\author{
Afshan Younas $^{1 *}$ and Aza Azlina Md Kassim² \\ ${ }^{1}$ Faculty of Business Studies, Arab Open University, Oman \\ ${ }^{2}$ Faculty of Business \& Accountancy, University of Selangor, Malaysia
}

\section{ARTICLE INFO}

Keywords:

Board Size

Board composition

Board tenure

Capital structure

\begin{abstract}
Board of directors are considered as an important proxy of corporate governance mechanism. Corporate governance plays a significant role in the development structure of stock market and businesses growth. In Gulf Cooperation Council region Oman is the first country to developed and adopt corporate governance mechanism. Oman holds a prominent position in the Middle East and North Africa region. The Omani economy basically depends on oil, gas and services sector. Due to oil crisis from 2015, Oman economy witnessed many challenges like rise in oil prices, unemployment and unfavorable balance of payment. On the other hand, the country encountered unfavorable debt level of the companies that made business companies unable to repay their loans. Therefore, this study proposes to explore conceptual model on the effect of board size, board composition and board tenure toward companies leverage. Though corporate governance mechanism is strong in developed countries, but the concept is still developing and progressing in Oman. Due to the current situation of Oman this study incorporates important proxies of corporate governance namely board structure, board composition and board tenure. Since the extensive research on corporate governance has been conducted but this relationship still not clearly established in developing countries specifically in context of Oman. Thus, this study provides a better and clear understanding on how the board size, board composition and board tenure impact and change capital leverage. In order to carry out this research, this study intended to collect secondary data from annual reports of listed companies at Muscat Securities Market. The discussions suggest the government and regulatory bodies' that have strong corporate governance implication and practices may reduce the debt burden of the companies. The high proportion of leverage in capital structure may threaten the companies to bankruptcy or create negative image of firm in the financial market.
\end{abstract}

\section{Introduction}

It is acknowledged that financial development positively affects economic growth. Certainly, financial markets are supposed to improve their performance to accelerate the growth of economy. According to OECD MENA Report (2005), the growth and development record in Middle East and North Africa region is relatively less compare to developed countries of world. Thus, the strong financial and capital market provides an opportunity for economic development and growth in other sectors.

After the major financial scandals in 2002 of large organizations like Enron and WorldCom, the attention towards the corporate governance started to rise extensively (Ali, 2016). There are significantly increase in the number of researches and publications in the area of corporate governance. The mainstream of these researches was in business, accounting, finance, economic and management field.

\footnotetext{
*Corresponding author E-mail address: afshan@aou.edu.om, aafshan2009@hotmail.com 
Corporate governance is the system designed to direct and control management activities. The main pillars of corporate governance are identified as transparency, accountability, fairness and responsibility (CMA, 2016; OECD, 2004). Board structure is one of the important element of corporate governance (Bulathsinhalage \& Pathirawasam, 2017). This paper explores the conceptual model on the relationship between board structure and leverage.

\section{Literature Review}

\subsection{Board Structure}

Board of directors are responsible for advising and monitoring the management of the company. Therefore, board of directors are considered to play important and crucial role in the corporate governance mechanism, which align the interests of managers with all stakeholders. Zahra and Pearce (1989) identified the main two roles of the board: first, the board should monitor and control the activities of the management; second, enhance and keep positive relationship between management with all stakeholders (Pearce \& Zahra, 2007). The important variables of board structure are board size, board composition and board tenure has been studied in this conceptual model.

\subsubsection{Board Size}

Board size refers to number of directors on the board. The Cadbury Committee suggests an ideal board size should be between 8 to 10 members with an equal balance of executive (inside) and non-executive (outside) directors (Cadbury Report, 1992). Later Jensen argued that the recommended board size should be around 7 to 8 directors (Al-matar, Al-swidi, Hanim, \& Fadzil, 2014). Brown and Caylor (2004) also suggest that a board size between 6 to 15 members is ideal to get optimum benefit. Lipton and Lorch (1992) argued that board size should be small and limited and a board size of 8 to 9 members considered best for efficient coordination and decision making, because if the board has more than 10 directors then it is not easy to take decisions in time and come on consensus.

Board size is an important determinant of corporate governance effectiveness. Resource dependency theory suggest that increased in size may yield benefits to the form by providing an extended network of external environment and by securing a broader resource base (Pearce \& Zahra, 2007; Tarus \& Ayabei, 2016). Many studies showed positive relationship between board size and firm leverage (Njuguna \& Obwogi, 2015).

Tawfeeq, Alabdullah, \& Ahmed, (2018) studied the relationship between board size and capital leverage on 100 Jordanian non-financial firms. The result indicates board size has significant negative effect on capital leverage. Therefore, the greater financial leverage is a result of the existence of small board of directors.

Purag \& Abdullah, (2016) conducted research to evaluate the relationship between corporate governance and leverage of the Malaysian family owned company. The study used sample of 195 companies and covers three years observations which are 2009, 2010 and 2011. The data collected from annual report as data for non-financial attributes. The general findings show that there is an insignificant relationship between board size and debt ratio.

Njuguna \& Obwogi, (2015) investigated the relationship between board size and capital structure from 2009 to 2013 among listed companies in East Africa. The study was based on secondary data which was collected from annual reports for Listed companies. The result reveals that increase in board size result in higher capital leverage.

\subsubsection{Board Composition}

An effective board with optimal composition of independent and dependent director is important in order to help the board to accomplish its goals and ensure the success of the 
company (Tarus \& Ayabei, 2016). The composition of the board has direct effect on the company's activities. The board composition refers to the proportion of inside and outside directors, board of directors include both executive and non-executive directors. Executive directors refers to dependent directors which are also the employees of company, whereas nonexecutives directors refer to independent directors which are from outside the company (Alves, Couto, Alves, \& Barbosa, 2018; Bulathsinhalage \& Pathirawasam, 2017).

The Cadbury Report (1992) indicates that presence of non-executives (outside) directors should be effective in enhancing board independence and financial leverage (Cadbury Report, 1992). Nonexecutive directors are outside directors who offer checks and balances to protect the interests of shareholders, and inside directors, who are more concerned with more operational and day to day management activities. It has been argued that higher proportion of independent non-executive directors increases board effectiveness in monitoring managerial activities and as a result increases voluntary disclosures (Fama \& Jensen, 1983).

Purag \& Abdullah, (2016) conducted research to evaluate the relationship between board composition and leverage of the Malaysian family owned 195 companies. The general findings show that there is a significant negative relationship between board composition and debt leverage. The result concluded that high proportion of board composition is associated with lower debt ratio. Tarus \& Ayabei, (2016) investigated the relationship between board Composition and firm leverage. The results indicated that board composition has positive significant implications on firm leverage, which means higher representation of independent directors has a positive association with leverage because larger board is not only ineffective but also more prone to be controlled by CEO.

\subsubsection{Board Tenure}

Board characteristics are not limited to board size and composition only, board tenure is also important consideration while studying the board structure under corporate governance and its impact on capital leverage. In the previous literature CEO tenure is explored and discussed more as compare to board tenure (El-Habashy, 2018; Gupta, Mahakud, \& Debata, 2018; Kuo, Wang, \& Lin, 2015; Masidonda, Asrida, Musaid, \& Hehanussa, 2018; Masnoon \& Rauf, 2013; Ndaki, Beisland, \& Merslan, 2018; Peters, Miller, \& Kusyk, 2011; Saidu, 2019). Board tenure refers to number of years and length of years that board of directors served on board. Board Tenure reflects the possibility that board members' control over the monitoring of executives will increase as the average tenure period increases (Ombaba \& Kosgei, 2017).

Members of board with longer years to serve in board provide an opportunity to have deeper and better insight and understanding of firm-specific knowledge to deal effectively with strategic issues (Huang, 2013). Director tenure should be able to enhance a board's ability both to monitor and provide resources to the firm, and by so doing, reduce its risk of financial distress.

Some researchers argue that long tenure is associated with adherence to management allegiance hypothesis, that suggests that long tenure directors develop trust towards management. Due to more trust, their relationship become more friendly and they will be less likely to monitor their managers. Long board tenure may limit cognitive conflict among board members and may restrict the number of views and opinions that are openly discussed. As a result, board members may be slow to detect and react to certain legal violations committed within the firm (ElHabashy, 2018).

Ombaba \& Kosgei, (2017) examine the relationship between board tenure effect on financial structure. The study found there is positive significant relationship between board tenure and financial distress. This is due to management allegiance hypothesis which is associated with longer board tenure. Due to longer serving period board will be able to develop good and trustworthy relationship with management. 


\subsection{Capital Structure - Leverage}

The capital structure is the combination of debt and equity capital, it is the financial structure of a company in which a firm will decide that how the organization finance its investments through combination of debt and equity. Debt and equity differ in their nature. Debt capital refers to the amount of borrowed money from banks as loans. Equity capital refers to the funds of the firm which is hold by the owner or shareholders. The capital structure is about setting the optimal mix ratio between debt and equity to maximise the value of the business. The relationship between capital structure with decision making was first highlighted by Modigliani and Miller in 1958 (Hussainey \& Khaled, 2012). Later on, this relationship was discussed by many researchers Myers (1984), Berens and Cuny (1995), Barclay and Smith (2005) and Al Najjar and Hussainey (2011), but the determinants of capital structure are still unknown and different theories leads to different findings.

There is a common concern that good corporate governance practices positively impact on capital structure which further leads to healthy business activities and reducing agency conflicts. With a sound organization structure, where managers and shareholders have minimum conflicts will lead to easy and accessible capital resources. Lenders are more comfortable with such businesses where corporate governance practices are stronger (Masnoon \& Rauf, 2013).

Board of directors plays significant role in protecting the interest of shareholders and ensuring the maximum performance of internal management. Many researchers showed a positive relationship between board of directors and firm leverage (Purag \& Abdullah, 2016; Tarus \& Ayabei, 2016; Tawfeeq et al., 2018).

The capital structure undergone to many developments after the research of Modigliani and Miller (1985). Capital structure is defined as the debt to equity ratio, which determine the value of the firm. The proportionate between debt and equity was made under certain circumstances, including the absence of taxes, negligible transaction cost and lack of information asymmetry among market players. There are many scholars and researchers, who believe that a firm's capital structure is influenced by firms board of directors size and board of directors structure (Bulathsinhalage \& Pathirawasam, 2017; Callaghan, Padia, \& Muchemwa, 2016; El-Habashy, 2018).

Capital structure theory can be divided in two main categories, trade off theory and peckingorder theory. These theories can reflect different management behaviours in relation to financing decision, specifically in relation to the effect of board of directors (Alves et al., 2018). The trade-off theory and pecking order theories attempted to define the financing decisions in firms. The trade-off theory is based on assumption that the optimal capital structure can be achieved as trade-off between the benefit of debt financing and the cost of debt financing. While pecking order theory is based on assumption that firm prefers internal to external financing and debt to equity (Acaravci, 2015).

\section{Hypothesis Development and the Conceptual Model}

\subsection{Board Size and Leverage}

Board size is an important determinant of board structure. The relationship between board size and company leverage is still vague. Many researches result reveals that board size and firm's leverage are significantly negatively associated, some researches indicated positive results, while some results showed no relationship at all (Njuguna \& Obwogi, 2015; Purag \& Abdullah, 2016; Tarus \& Ayabei, 2016; Tawfeeq et al., 2018). The previous research on the relationship between board size and leverage was conducted mostly on developed countries, therefore study on board size and leverage is less explored in developing countries specially in Mena region. Thus, this study is highly demanded in context of Omani Public listed companies.

The study conducted in Malaysia 2018 indicated that greater financial leverage is the result of smaller board (Tawfeeq et al., 2018). While, the research conducted on Malaysian family owned business showed that there is no significant relationship between board size and debt leverage 
(Purag \& Abdullah, 2016). On the other hand, the research conducted on East Africa listed companies revealed that there is a positive relationship between board size and capital leverage. Obradovich \& Gill, (2013) conducted a research on the relationship between board size and leverage. The study used 333 firms listed on New York Stock Exchange for a period of 3 years from 2009-2011. The result reveals that larger board is negatively associated with leverage. Which means that when the board size increases the leverage falls because the more the members work on board will be in position to better monitor management policies in terms of financing assets.

Thus, it can be concluded that the board should be of sufficient size to fulfil the requirements of the business. Some countries restrict board size to 8 to 10 members, while others allow to maximum board size up to 16 . Oman code of corporate governance second Principle indicated that each company must be headed by an effective board of directors to lead the company, monitor its business and control its operations. Therefore, this relation needs to be tested in the context of Oman stock market. Thus, based on above discussion the following hypothesis is developed:

H1: There is significant negative relationship between Board size and leverage.

\subsection{Board Composition and Leverage}

Board composition is an important determination in firm's financial decision making. Board composition refers to ratio of independent and dependent directors. The composition of board has direct impact on company's activities. A balance board composition helps the firms in taking optimal financial decisions (P. Alves, Couto, \& Francisco, 2015). The Cadbury report indicated that presence of independent (outside) director impacts positively on firm's financial leverage. The existence of outsider directors works as a controlling and monitoring mechanism on the management activities (Cadbury Report, 1992)

It has been argued that presence of outside directors increases the effectiveness of management activities and thus improves the volunteer disclosure of firm's information (Fama \& Jensen, 1983). The study conducted on East African Listed companies results reveals that there is need to incorporate outside directors in the mechanism to minimise agency cost (Njuguna \& Obwogi, 2015). Another study done on Malaysian family owned business also showed negative results between independent directors and debt leverage. Thus, based on above discussion, the following hypothesis is proposed for study:

$\mathrm{H} 2$ : There is significant negative relationship between Composition of independent directors and leverage.

\subsection{Board Tenure and Leverage}

Board tenure is also important variable of board structure. In the literature of board structure CEO tenure is studied more. The variable board tenure is still less explored and specifically not clearly explored in context of Oman. Different researches revealed contradictory results on board tenure. It has been argued that longer number of years to serve on board provides an opportunity to have more better and deeper insight about company's matters (Huang, 2013). On contrary, with larger number of years on board, directors will have good and trusty relationship towards management. Due to more trust, their relationship become more friendly and they will be less likely to monitor their managers (Ombaba \& Kosgei, 2017).

It is very important to explore the relationship between board tenure and capital leverage. Therefore, it can be assumed that with long number of years directors will be in a position to understand the firm's matter in more detailed and able to control and rectify any adverse financial affect. Thus, the following hypothesis is proposed for the current study:

H3: There is significant negative relationship between Board tenure and leverage. 


\subsection{Conceptual Model}

The conceptual framework is a schematic presentation of the variables under investigation. In the current study the relationship between independent variables and dependent variable is visualized as below in Figure 1. The study hypothesizes that there is a relationship between board characteristics and capital structure among the listed companies in Muscat Securities Market.

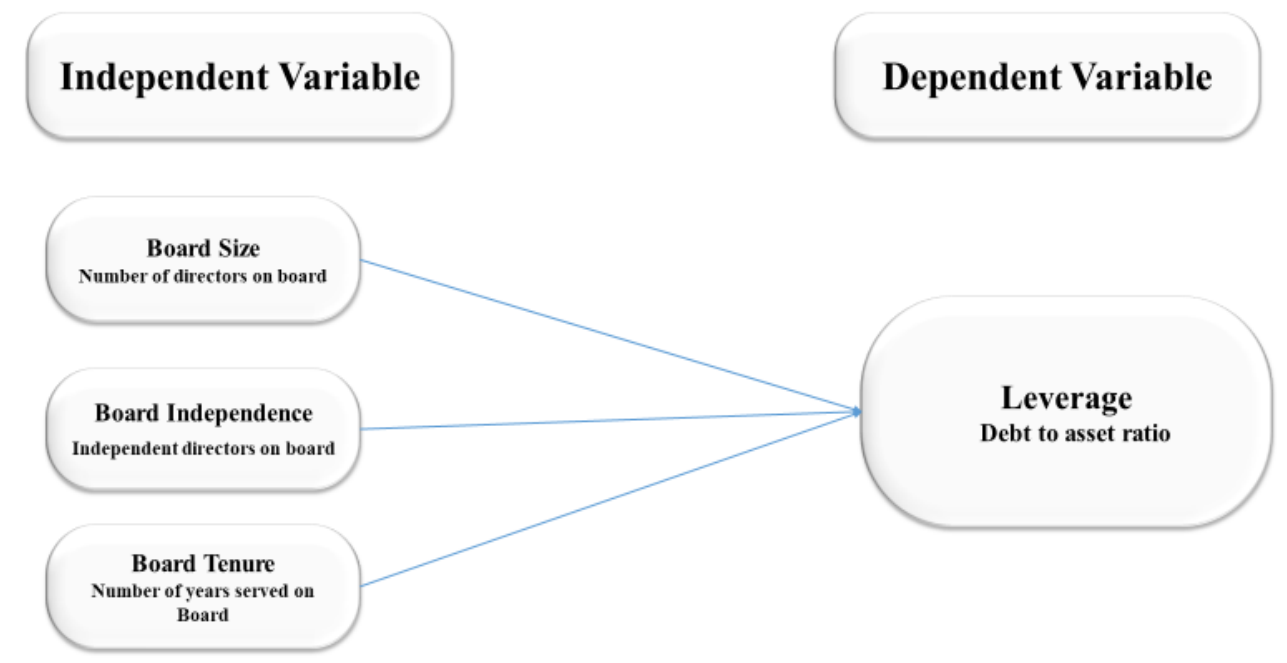

Figure 1. Relationship between Board of Directors and Leverage

\section{Research Methodology}

\subsection{Use of Secondary Data}

This study seeks to examine the relationship between board size, board composition and board tenure on the firm leverage. This study will use secondary data gathered from the annual reports of companies listed at Muscat securities market (MSM) from 2016 to 2019. This study basis on the annual reports which are published by listed companies. If needed, then study will be further supported with direct interviews with the executive of a selected firms as sample.

\subsection{Sample Size and Data Collection}

This study has chosen Oman public listed companies as a unit of analysis. In order to carry out research, the study will use the full population as sample. There are 117 companies listed at Muscat Securities Market in different sectors. The annual reports will be used for secondary data collection. Annual reports are available on Muscat Securities Market and as well as on the website of the company.

\subsection{Measurements}

In this study two sets of variables are added such as Board structure and company leverage. The leverage ratio represents the company debt to asset ratio. The three elements of board structure such as board size, composition and tenure have been undertaken with the reliable and valid instruments collected from the past studies. Board size refers to number of directors serve on board, board composition denoted to number of independent directors on board and board tenure will be represented in the length or number of years to serve on board.

\section{Potential Contribution}

The previous studies conducted on board structure and capital leverage on developed countries (Alves et al., 2018; Obradovich \& Gill, 2013; Saiful, Puteh, Branch, Campus, \& Nawawi, 2018). On the other hand, the study conducted on Muscat securities market are based on board structure and financial performance (Al-matar et al., 2014; Al-matari, Al-Swidi, \& Fadzil, 2014; Y1lmaz, 
2018). There is still limited research in Oman in the areas of board structure influence on capital leverage. Therefore, this study is very important and contribute in context of Omani market.

Moreover, there is still inadequate number of studies in the relationship between board composition and capital leverage. Based on different previous researches the results are vague and no any conclusion has been concluded in terms of board composition role on capital leverage. Therefore, there is need of further research to be conducted in developed countries to clear and highlight the relationship between the variables.

It is believed that the results of this study will provide the top management a better understanding on the role of strong board structure in lowering financial leverage. The study results will be share with the CMA (Capital Market Authority) and MSM (Muscat securities Market) to understand the need and use of corporate governance mechanism as a controlling mechanism. The better knowledge regarding the relationship between board size, composition and tenure with leverage will enable investors, banks and other stakeholders to understand and compare the companies leverage. The results of this study will be helpful for the stakeholders in their decision-making process.

\section{Conclusion}

From the previous studies it has been concluded that board composition has an important impact on capital leverage. The relationship has been established and tested mostly in developed countries, but not in the context of Oman stock market. Strong board composition impacts optimally on capital leverage. Increase in board size, balance composition of independent directors and limited board tenure leads to optimal capital structure. The relationship between dependent and independent variable is still vague and dynamic in context of different economies, so it is highly demanded to study this relationship in context of Oman. Finally, this study will also contribute in literature in Oman context, as well as provide better insight to decision maker and industry players.

\section{References}

Acaravci, S. kakilli. (2015). The Determinants of Capital Structure Choice. International Journal of Economics and Financial Issues, 5(1), 158-171. https://doi.org/10.1111/j.15406261.1988.tb02585.x

Al-matar, E. M., Al-swidi, A. K., Hanim, F., \& Fadzil, B. (2014). The Effect of Board of Directors Characteristics, Audit Committee Characteristics and Executive Committee Characteristics on Firm Performance in Oman : An Empirical Study The Effect of Board of Directors Characteristics, Audit Committee Characteristics . (January 2016). https://doi.org/10.5539/ass.v10n11p149

Al-matari, E. M., Al-Swidi, A. K., \& Fadzil, F. H. B. (2014). The Effect of the Internal Audit and Firm Performance.pdf. International Review of Management and Marketing, 4(1), 34-41.

Ali, M. (2016). Impact Of Corporate Governance On Firm s Financial Performance (A Comparative Study Of Developed And Non Developed Markets). Arabian Journal of Business and Management Review, 6(6), 15-30. https://doi.org/10.4172/22235833.1000272

Alves, P., Couto, E. B., \& Francisco, P. M. (2015). Board of directors' composition and capital structure. Research in International Business and Finance, 35, 1-32. https://doi.org/10.1016/J.RIBAF.2015.03.005

Alves, P. F. P., Couto, E., Alves, P., \& Barbosa, E. (2018). Board of directors ' composition and capital structure Research in International Business and Finance Board of directors ' composition and capital structure. Research in International Business and Finance, 35(April 
2015), 1-32. https://doi.org/10.1016/j.ribaf.2015.03.005

Bulathsinhalage, S., \& Pathirawasam, C. (2017). The Effect of Corporate Governance on Firms' Capital Structure of Listed Companies in Sri Lanka. Journal of Competitiveness, 9(2), 19-33. https://doi.org/10.7441/joc.2017.02.02

Cadbury Report. (1992). The Financial Aspects of Corporate Governance. 27(3), 68. Retrieved from http://www.icaew.com/ /media/corporate/files/library/subjects/corporate governance/financial aspects of corporate governance.ashx

Callaghan, C. W., Padia, N., \& Muchemwa, M. R. (2016). Board Composition, Board Size and Financial Performance of Johanneseburg STock Exchange Companies. 19(4), 497-513. https://doi.org/: http://dx.doi.org/10.17159/2222-3436/2016/v19n4a

CMA. (2016). Oman Code of Corporate Governance. (July 2015).

El-Habashy, H. A. (2018). Determinants of Capital Structure within the Context of Corporate Governance in Egypt. International Journal of Business and Management, 13(8), 26. https://doi.org/10.5539/ijbm.v13n8p26

Fama, E. F., \& Jensen, M. C. (1983). Separation of Ownership and Control Separation of Ownership and Control. Journal of Law and Economics, 26(2), 301-325. https://doi.org/10.1086/467037

Gupta, G., Mahakud, J., \& Debata, B. (2018). Impact of CEO's characteristics on investment decisions of Indian listed firms : Does crisis make any difference ? Cogent Economics \& Finance, 11, 1-15. https://doi.org/10.1080/23322039.2018.1439258

Huang, S. (2013). Board Tenure and Firm Performance. European Accounting Association, (May), 1-58.

Hussainey, K., \& Khaled, A. (2012). Corporate Governance Mechanisms and Capital structure in UAE. Journal of Applied Accounting Research, 13(July), 145-160. https://doi.org/10.1108/09675421211254849

Kuo, H., Wang, L., \& Lin, D. (2015). CEO Traits, Corporate Performance, and Financial Leverage. 7(1), 68-86. https://doi.org/10.5539/ijef.v7n1p68

Masidonda, J. La, Asrida, W., Musaid, S. A., \& Hehanussa, S. J. (2018). Effect of CEO Ability, Ownership and Profitability on Corporate Value Mediated by Capital Structure. 9(6), 10561066.

Masnoon, M., \& Rauf, M. (2013). Impact of Corporate Governance on Capital Structure - A study of KSE listed Firms. Gmjacs, 3(1), 94-110.

Ndaki, D. P., Beisland, L. A., \& Merslan, R. (2018). Capital structure and CEO tenure in microfinance institutions. Strategic Change, (July). https://doi.org/10.1002/jsc.2205

Njuguna, C. W., \& Obwogi, T. N. (2015). Relationship between board characteristics and capital structure among companies listed in East Africa. 3(10), 355-372.

Obradovich, J., \& Gill, A. (2013). The Impact of Corporate Governance and Financial Leverage on the Value of American Firms.

OECD. (2004). Organisation for Co-operation and Economic Development. OECD Principles of Corporate Governance, $66 . \quad$ Retrieved from https://www.oecd.org/corporate/ca/corporategovernanceprinciples/31557724.pdf

Ombaba, K. M. B., \& Kosgei, D. (2017). Board Composition and Financial Distress of Listed Firms in Kenya . An Empirical Analysis. 6(4), 75-93. 
Pearce, J. A., \& Zahra, S. A. (2007). Board composition from a strategic contingency perspective. (October 2017). https://doi.org/10.1111/j.1467-6486.1992.tb00672.x

Peters, S., Miller, M., \& Kusyk, S. (2011). How relevant is corporate governance and corporate social responsibility in emerging markets? Corporate Governance. https://doi.org/10.1108/14720701111159262

Purag, M. Bin, \& Abdullah, A. B. (2016). Corporate governance and capital structure of Malaysian family-owned companies. Journal of Business and Retail Management Research, 11(1), 18-30.

Saidu, S. (2019). CEO characteristics and firm performance : focus on origin, education and ownership. 7.

Saiful, A., Puteh, A., Branch, P., Campus, T., \& Nawawi, A. (2018). The Impact of Audit Committee Independence and Auditor Choice on Firms ' Investment Level. Journal of Social Sciences and Humanities, (October).

Tarus, D., \& Ayabei, E. (2016). Board composition and capital structure : evidence from Kenya Management Research Review Article information: Management Research Review, 39(September 2016), 1056-1079. https://doi.org/10.1108/MRR-01-2015-0019

Tawfeeq, T., Alabdullah, Y., \& Ahmed, E. R. (2018). Board Features and Capital Structure in Emerging Markets. Journal of Advanced Management Science, 6(2), 74-80. https://doi.org/10.18178/joams.6.2.74-80

Y1lmaz, İ. (2018). Corporate Governance and Financial Performance Relationship: Case for Oman Companies. Journal of Accounting Finance and Auditing Studies (JAFAS), 4(4), 84106. https://doi.org/10.32602/jafas.2018.006 